\title{
Language Policy on Education in Nigeria: Challenges of Multilingual Education and Future of English Language
}

\author{
Jalaludeen Ibrahim \& Sadiya A. Gwandu \\ Department of European Languages, Federal University Birnin-kebbi, Nigeria \\ jalalmaradun@gmail.com
}

\begin{abstract}
Despite the fact that the importance of language is recognized in National Policy on Education (NPE), the language of instruction in multilingual Nigeria has always been a matter of concern to educators and educational planners. This study investigated the current situation of educational policy in Nigeria, highlighting the challenges of multilingual education and future of English language. A total number of one hundred (100) teachers at basic education level (this comprises lower primary and junior secondary school as contained in the National Policy on Education) in Gusau the capital city of Zamfara State, Nigeria, were selected as participants. The findings revealed that provisions of multilingual education contained in the National Policy on Education are not properly implemented by the majority of the teachers and the government has not taken the implementation of the provisions any serious. The findings also revealed that the future of English in the Nigerian educational sector is very bright since it now seems to be the language of officialdom. The findings further revealed that some of the challenges of multilingual education provisions include: the multilingual challenge; poor policy planning and implementation; and teacher quality and curriculum materials. This study recommends that the Federal Government of Nigeria should do more in the enforcement of the multilingual provisions in all sectors of education and also develop more educational resources and orthographies of indigenous languages to meet the demands of multilingual education.
\end{abstract}

Keywords: Education, English, Language, Multilingual, National, Nigeria, Policy

\section{INTRODUCTION}

In Nigeria, language policy on education dates back to the colonial era when in 1927 the British Advisory Committee on native education in tropical Africa recommended that indigenous languages should serve as medium of instruction in the lower years of primary education (Musa R.J., 2010). Language policy on education which passed through many stages is a pressing contemporary concern in the highly multi-ethnic and multilingual Nigeria of about 500 indigenous languages spoken within its borders (Blench R., 2002). English language was the medium of instruction before the National Policy on Education advocated the use of indigenous languages in teaching at basic level of education.

Language plays different roles such as officialdom, legislature, mass media, politics, official business, education etc. in a particular setting. The scope of this study is the role of language in education. Language here can either be language learnt and taught in the educational system or the language used for educating at various levels and sectors of a national system (Obanya, 2004). This review deals with the use of languages in education both as languages learnt/taught and used for instructional reasons. The Encyclopaedia defines multilingualism as the use of several languages either by an individual speaker or by a community of speakers. Multilingual education in this context is therefore, the use of several languages in educational system.

Terry (1977) sees policy as "an overall guide that gives the general limits and direction in which administrative action will take place." This implies that policy only defines the area in which decisions can be made but cannot give the decision, instead ensures consistency of an action since an administration is governed by approved principles. The concentration here is on Educational policy which gives the direction for educational activities. 
Despite the fact that the government through the National Policy on Education can be said to favour the use of two or more languages in the educational system, implementation of the multilingual provisions has been a serious issue. In an attempt to find out the different factors responsible for the poor implementation of these provisions, scholars have a list of some challenges (Olagbaju, 2014) which include:

- Multi-lingual challenge;

- Negative attitudes of students;

- Lack of curriculum materials;

- Ambiguities in the policy;

- Parental factors;

- Teacher quality.

Having outlined the possible contemporary issues facing the implementation of complete use of indigenous languages as medium of instruction in schools, a research was carried out to study the current state of educational policy in Nigeria, highlighting specific issues on the challenges of multilingual education and future of English language. This study also tries to examine the effectiveness of the English language in the advancement of the nation's educational sector, with the hypothesis that provisions of multilingual education contained in the National Policy on Education (NPE) are not properly implemented. In achieving the set objectives of this study, the following questions were raised:

1. Are educational goals in line with educational policies in Nigeria?

2. Do schools implement the multilingual provisions of the NPE?

3. What according to teachers is the students' perception of multilingual education?

4. What is the status of multilingual education provisions of the NPE in Nigeria?

5. What skills have teachers acquired in the English language?

6. What is the future of English language in the Nigerian educational sector?

\section{Multilingual Policy On Language Education In Nigeria}

The language of instruction in multilingual Nigeria has always been a matter of concern to educators and educational planners. The African situation is aptly captured by Ouadraogo (2000) when he asserts that, "education and language issues are very complex in Africa because of the multi-ethnic and multi-lingual situations". Due to this linguistic plurality, the government appreciated the importance of language as a means of promoting social interaction and national cohesion as well as preserving culture. Thus, there was the need for language policy, planning and development as well as implementation. In 1977, an official document titled National Policy on Education was promulgated which was revised in 1981, 1998 and 2004. This document assigned different functions to the many Nigerian languages in the nation's education at various levels. The policy stated that every child shall learn in the language of the immediate environment in the first three years while English language shall be taught as a school subject. However, in the interest of national unity among the various ethnic groups in Nigeria, every child shall require to learn one of the three national languages (Hausa, Igbo, Yoruba).The provision of the NPE (2004), Section 4, Paragraph 19 (e) and (f) cited below confirms that the multilingual education is in existence:

The medium of instruction in the primary school shall be the language of the environment for the first three years. During this period, English shall be taught as a subject. rom the fourth year, English shall progressively be used as a medium of instruction and the language of immediate environment and French shall be taught as subjects. 
The policy made it explicit that from the fourth year of basic education, the medium of instruction shall be English language while the language of the immediate environment and French shall be taught as subjects. At secondary level, English shall be the language of instruction while the language of the immediate environment, one of the three major Nigerian languages (Hausa, Igbo, Yoruba) other than that of the immediate environment and French shall be taught as school subjects (Olagbaju, 2014).Levels of Education in Nigeria are:

1. Early childhood (pre-primary);

2. Basic education (9 years) - comprising Primary and Junior Secondary Education;

3. Senior Secondary Education (3 years);

4. Tertiary Education.

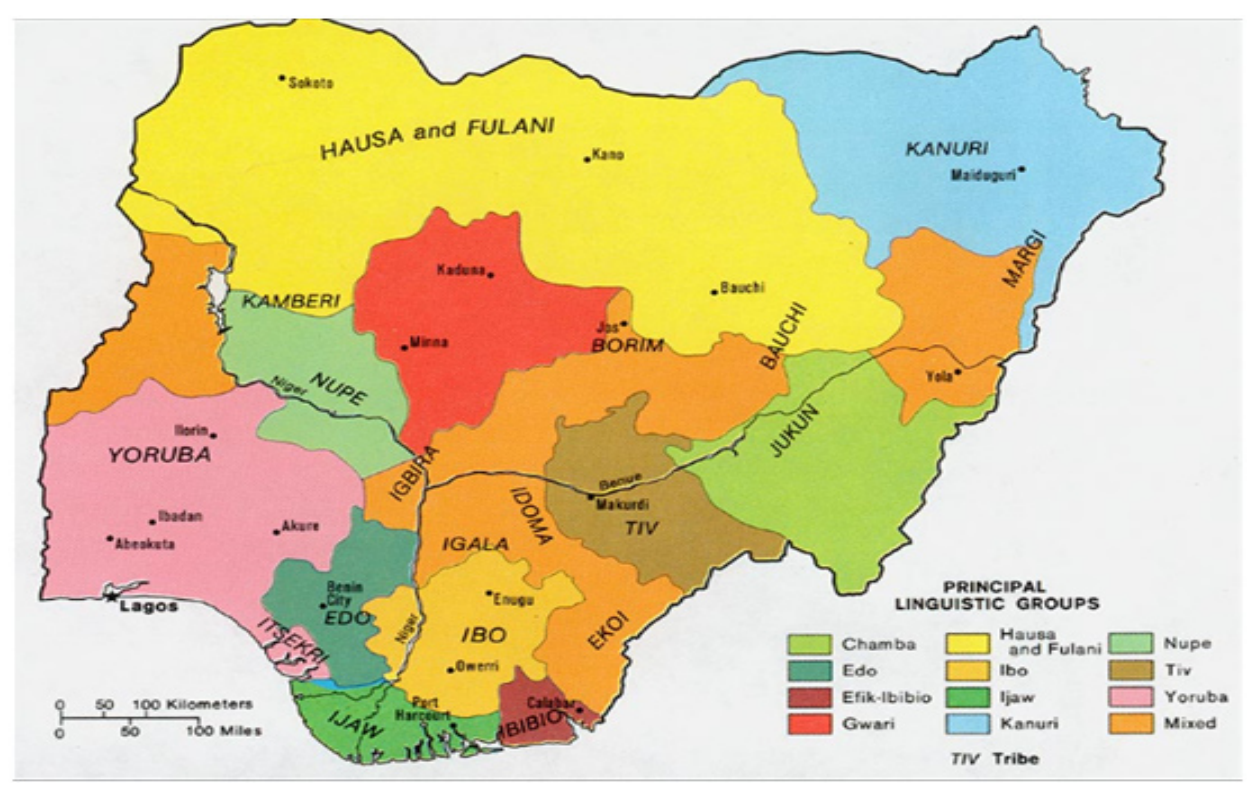

Fig1. Map of Nigeria showing linguistic groups

\section{Role OF ENGLiSH LANGUAge In Nigeria}

Decades after decolonisation, English being the language of the colonial masters still enjoys primacy through its significant role in the integration of the Nigerian nation that is made up of three different regions of North, East and West. Hausa is the predominant language of the northerners, Igbo of the Easterners and Yoruba of the Westerners. Each region has many other minority groups within it. Nigeria's multiplicity of languages is so obvious that languages of people living within a 20 kilometres radius are particularly different and not understandable to one another (Danladi, 2013). The implication of this linguistic situation has been the lack of a common effective means of communication among the groups and this became the basis for resorting to use the English language as a medium of instruction in educational settings, since the choice of any of the three main native languages as a national language may deteriorate to disintegration. According to Odebunmi (2005), English is institutionally the only means open to individuals from different ethnic and linguistic groups for interaction. This shows the dominance of English in the Nigerian setting.

From earliest stage to date, English has been playing dual roles as a contact language between different ethnic groups and a medium of communication at international levels particularly in the area of commerce and diplomacy, though in different usages. Despite all constitutional provisions, English still controls almost all 
methods of instructions in all levels of education in Nigeria, while Hausa, Igbo and Yoruba are considered as local languages. English is that Language of unity that speakers of other indigenous languages do code-mix with in their speech. Other speakers see Pidgin English as lingua franca in Nigeria. Scholars have identified five dominant roles of English and other mother tongues in Nigeria as: official, educational, mass media, religious observance, and interpersonal relations. However, these roles played by English language can be rooted in its colonial history.

\section{Methodology}

In the cause of this study, a total number of one hundred (100) teachers at basic education level (this comprises lower primary and junior secondary school as contained in the National Policy on Education) in Gusau the capital city of Zamfara State, Nigeria, were selected as participants. The schools in Gusau were stratified into public and private schools, after which four schools were randomly selected; two from each category. Twenty five (25) teachers were selected through a simple random sampling technique from each school. A twentyitem questionnaire was developed and administered to the teachers of relevant subjects to find out students' perception of multilingual education, status of multilingual education provisions on the NPE, teachers' skills in the English language and future of English language in Nigeria. The instrument was divided into four parts to cater for four variables. Each part has five (5) questions four (4) of which were in a "yes", "no", and "not sure" scale - the fifth question in each part was open-ended, mainly to allow the respondents to express themselves appropriately. The participants were told to be objective in the process of responding to the questions. The data were analysed using frequency counts and percentages.

\section{RESULTS AND Discussion}

Table1. Students Perception of Multilingual Education

\begin{tabular}{|l|l|}
\hline Q1 & Students prefer to be taught in the English language rather than the indigenous language. \\
\hline Q2 & $\begin{array}{l}\text { Students demonstrate more passion for learning when you switch to an indigenous language in a class- } \\
\text { room setting. }\end{array}$ \\
\hline Q3 & Students comprehend better when you explain a topic in an indigenous language. \\
\hline Q4 & $\begin{array}{l}\text { Students feel teaching with indigenous languages may not prepare them well for international exami- } \\
\text { nations. }\end{array}$ \\
\hline
\end{tabular}

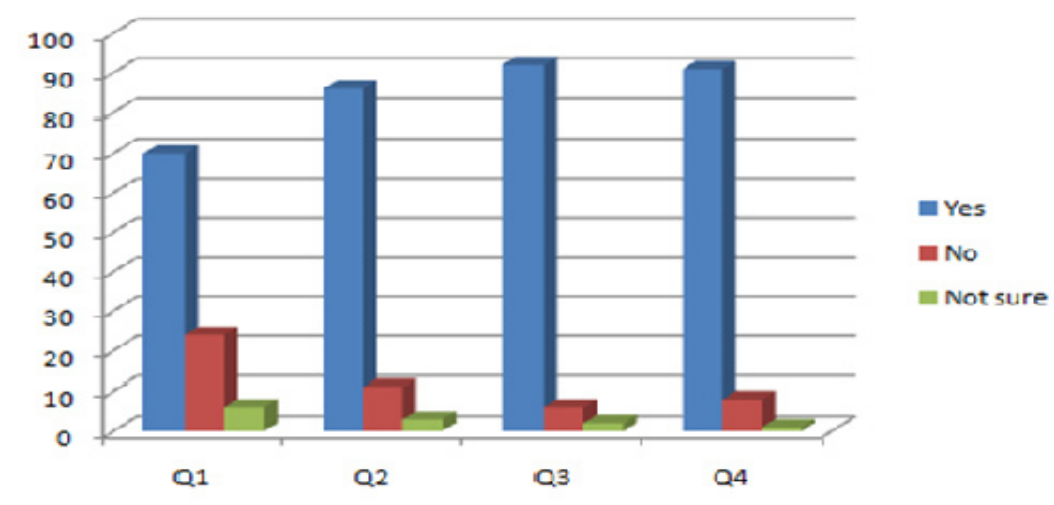

Fig2. Percentage Rates of Responses for Students' Perception of Multilingual Education 
From the analysis shown in table 1 and figure 2, 70 per cent of the students are reported to prefer to be taught in English language to any of the indigenous languages while 24 per cent are comfortable with indigenous language as the medium of instruction. 6 per cent are not sure. The rate of school teachers who are of the opinion that students demonstrate more passion for learning when the teacher switched to an indigenous language in a classroom setting is 86 per cent. 11 per cent feel that practicing multilingual education in the classroom is not any significant to students' passion for learning while 3 per cent of the respondents are not sure. 92 per cent of the respondents believe that students comprehend better when taught in the indigenous languages while 6 per cent feel otherwise. 2 per cent of the respondents are not sure. 91 per cent of the respondents reported that the students feel that multilingual education cannot prepare them for international exams while 8 per cent reported otherwise. Only 1 per cent is not sure.

Table2. Status of Multilingual Education Provisions of the National Policy on Education

\begin{tabular}{|l|l|}
\hline Q1 & Are you aware of the provisions of National Policy on Education on indigenous languages? \\
\hline Q2 & Have you been implementing the multilingual provisions of the National Policy on Education? \\
\hline Q3 & $\begin{array}{l}\text { Is implementing the multilingual provisions of the National Policy on Education not necessary for stu- } \\
\text { dents' success in education? }\end{array}$ \\
\hline Q4 & Are there available textbooks and other relevant teaching materials in indigenous languages? \\
\hline
\end{tabular}

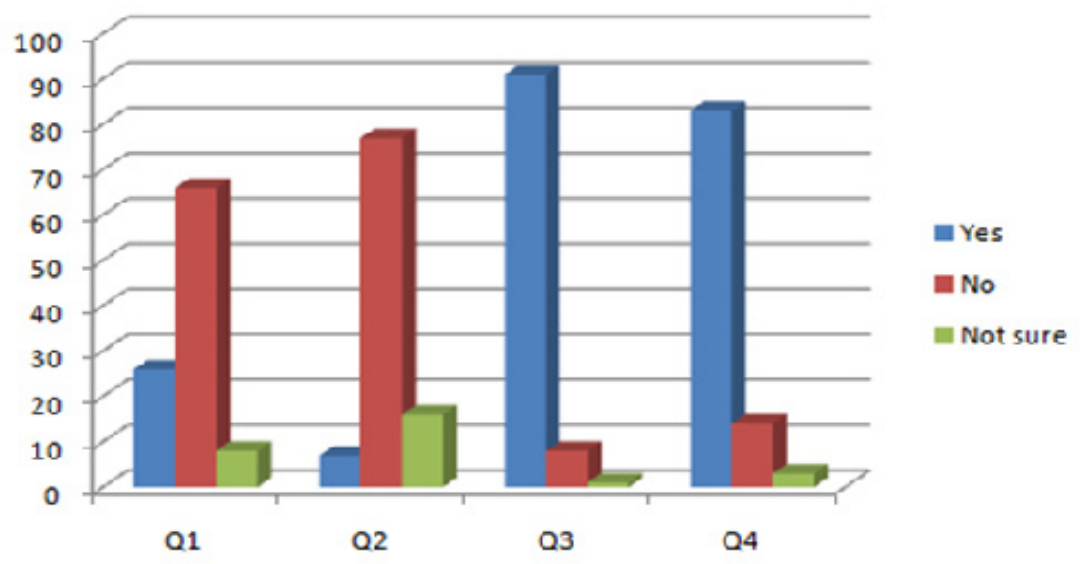

Fig3. Percentage Rates of Responses for Status of Multilingual Education Provisions of the National Policy on Education

Table 2 and figure 3 show that only 26 per cent of the teachers used for this study are aware of the existence of the multilingual provisions of National Policy on Education. 66 per cent are not familiar with the multilingual provisions while 8 percent are not sure. Only 7 percent of the teachers have been implementing the multilingual provisions of the National Policy on Education while 77 per cent have not been implementing these provisions. 16 per cent of the respondents are not sure. 91 per cent of the respondents are of the opinion that it is not necessary to implement the multilingual provisions of the National Policy on Education, 8 per cent feel otherwise while 1 percent is not sure. Only 14 per cent of the teachers used for this study have relevant materials for teaching in the indigenous languages, 93 per cent lack the relevant teaching materials while 3 per cent are not sure. 
Table3. Teachers' Skills in the English Language

\begin{tabular}{|l|l|}
\hline Q1 & Are you proud of your skills in the English language? \\
\hline Q2 & Do you speak English at home? \\
\hline Q3 & Do you write English with difficulty? \\
\hline Q4 & Is using English as natural to you as your mother tongue? \\
\hline
\end{tabular}

Table 3 and figure 4 reveal that 62 per cent of the teachers used for this study are proud of their skills in the English language, 30 per cent of the teachers are not proud of their skills in the English language while 8 per cent are not sure. 29 per cent of the teachers speak English language outside school setting, 65 of the respondents do not speak English language at home, while 6 per cent are not sure. 46 per cent of the teachers feel that they find it difficult writing English, 53 of the teachers do not find it difficult to write English, while 1 per cent is not sure. Only 3 per cent of the respondents feel that their use of English language is as natural as their mother tongue, 95 percent of the respondents feel otherwise, while 2 per cent are not sure.

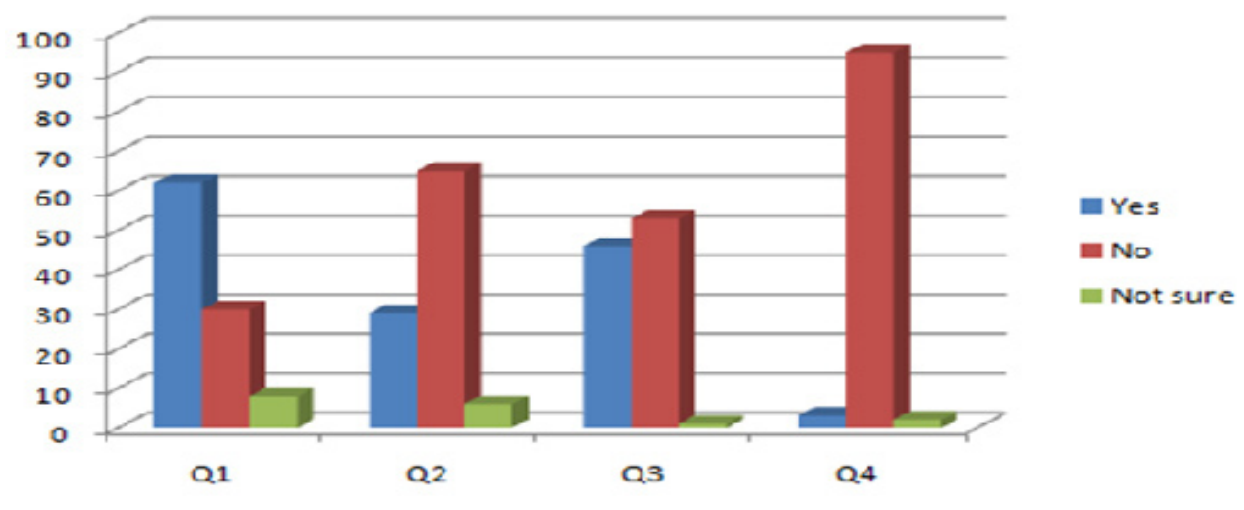

Fig 4. Percentage Rates of Responses for Teachers' Skills in the English Language

Table4. Future of English Language in Nigeria

\begin{tabular}{|l|l|}
\hline Q1 & In 30 years' time, is it likely that English will be the only language of instruction in Nigerian schools? \\
\hline Q2 & In 30 years' time, would any of the indigenous languages be able to compete with English language? \\
\hline Q3 & $\begin{array}{l}\text { In } 30 \text { years' time, would you believe that there will be more English lessons in basic education than } \\
\text { now? }\end{array}$ \\
\hline Q4 & $\begin{array}{l}\text { In } 30 \text { years' time, would you believe that Nigerians who couldn't speak English will be seen as outsid- } \\
\text { ers? }\end{array}$ \\
\hline
\end{tabular}

78 per cent of the teachers used for this study reported that in the next 30 years, there is every possibility that English language will be the only medium of instruction, 10percent of the respondents reported otherwise while 12 per cent are not sure. Only 1 per cent of the respondents reported that in the next 30 years, there might be an indigenous language that may compete with English language as a medium of instruction, 94 per cent reported otherwise while 5 percent are not sure. 83 per cent of the respondents believe that in the next 30 years there will be more English lessons in schools than what is obtained now, 13 per cent of the respondents reported otherwise, while 4 percent are not sure. 33 per cent of the respondents are reported to be of the belief that in the next 30 years Nigerians who couldn't speak English language will be seen as outsiders, 58 reported otherwise, while 9 are not sure. 
However, the responses obtained from the open-ended questions further confirm the findings in each section. Majority of the examples given as responses in the first section are in favour of students' preference for English language as a medium of instruction even when they understand better when being taught in the indigenous languages.

In the second part of the questionnaire where asked opinions about the practice of multilingual education provisions as stated in the National Policy on Education in Nigerian schools, majority of the responses are of the belief that the practice of the provisions is not in any way encouraging.

The third section on the key roles of English language in the Nigerian education sector is where the participants responded most. Majority of the respondents have affirmed that English language is the only language that brings multilingual Nigeria together having being the only language of medium of instruction in use in almost every part of the country. They also see it as official language and also as language of the media.

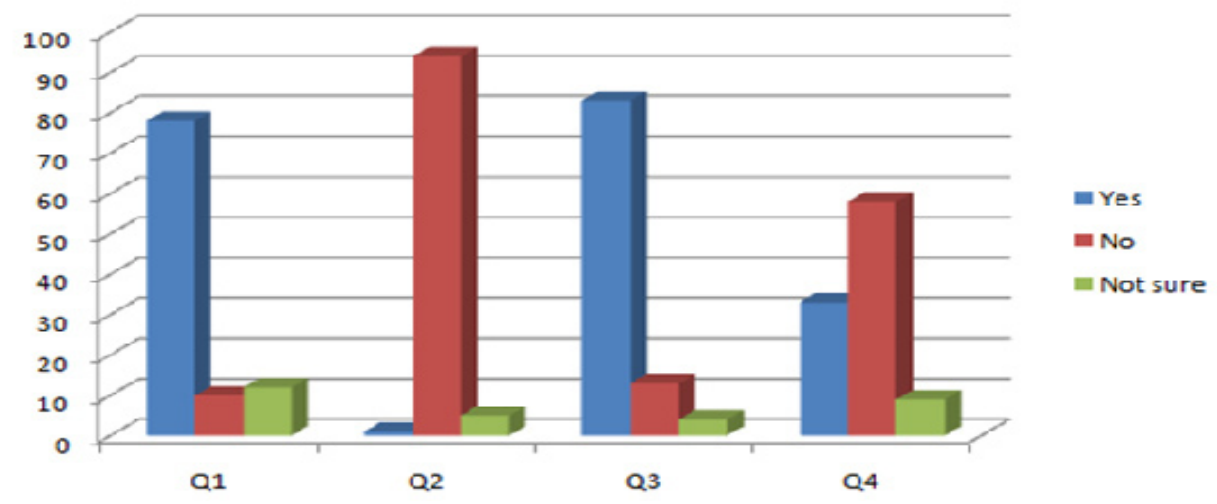

Fig5. Percentage Rates of Responses for Future of English Language in Nigeria

The last question in the last section which asked views about the future of English language in Nigeria, also elicited lots of responses. Most of the respondents are of the view that English will continue to play its role as the language of officialdom, media and instruction in Nigeria in the future.

In sum, students understand better when being taught in the indigenous language but they prefer to be taught in the English language which prepare them more for national and international exams in order to meet with the demands of new age. English language has a bright future in the Nigerian educational sector.

\section{SUMMARY OF FINDINGS}

From the results discussed above, this study arrives at the following deductions:

- Students prefer to be taught in English language but they demonstrate more passion for learning when switched to an indigenous language;

- Majority of the teachers have not been putting into practice the multilingual provisions of the National Policy on Education;

- The government has not taken the implementation of the provisions any serious;

- No competent teachers to handle school subjects in the indigenous languages;

- No adequate textbooks and other relevant teaching materials in indigenous languages;

- Teachers are proud of their skills in the English language even when they don't see it as natural as their indigenous languages; 
- Indigenous languages cannot compete with English language in the future;

- The future of English language in the Nigerian educational sector is very bright.

Challenges of Multilingual Education Provisions in Nigeria The Multilingual Challenge

In plurilingual Nigeria, it is obvious that the estimated 500 different languages are of unequal statuses. This inequality confirms that linguistic hierarchy is a serious concern in the Nigerian linguistic situation. Consequent upon Nigeria's linguistic diversity is the issue of national unity and cultural integration of the people. This nonexistence of linguistic unity among citizens led to the emphasis placed on English language in the educational sector. Gbenedio (1990) discovered that only about 65 standardised orthographies and only three major languages of Hausa, Igbo and Yoruba have documented efforts of teacher education. In the case of this situation, the challenge is the identification, development and adoption of about five hundred (500) languages for the basic education in the country. Any attempt to compress similar languages in a particular region to promote one that would represent the cultural area would meet with opposition and complaint about marginalisation from the communities, even when majority of languages don't have standard orthographies. Ogunbiyi (2008) emphasises that in spite of the provisions of the National Policy on Education and the position of the government on the roles assigned to the English language and indigenous languages in education, some schools still downgrade Nigerian languages to the background and promote the teaching of English language, most especially the private schools.

\section{Poor Policy Planning \& Implementation}

Although the use of the child's mother tongue as a medium of instruction for the first three years of basic education as stated in the National Policy on Education (NPE, 2004) is ideal, numerous factors have contributed to the low attainment of the educating goals of basic education in Nigeria. Leading among the factors is poor planning. Implementation of educational policies can only succeed to stand the test of time when after the policy formulation, the planning stage is well handled. Okeke et al (1985) opine that good planning will ensure effective implementation. Aghenta (1984) observed that, "for education to achieve all ends, it has to be carefully planned. The plan must take into consideration... the needs of the society; the political, socio-cultural, economic, military, scientific, and technological realities of the environment are very important to its survival."

\section{Teacher Quality and Curriculum Materials}

Another key challenge that contributed to the unsuccessful implementation of the multilingual policies on education in Nigeria is capability problem. There is low turnout of competent teachers in the various indigenous languages to handle school subjects, in other words, there are no graduate teachers of indigenous languages in the right quantity and quality. There is non-availability of teaching materials particularly relevant textbooks in the indigenous languages. It is very common in the Nigerian setting to see that there are many school teachers who don't know how to read or write their native languages. Speaking a language (with semantic errors) alone is not enough to qualify a teacher to teach that language. Only quality teachers can succeed in proper implementation of any curriculum. This is an unfortunate situation but that appears to be the handwriting on the wall.

\section{RECOMMENDATIONS}

In line with the entire discussions in this review, the following recommendations may proffer solution for a workable multilingual policy for Nigeria:

- The Federal government should fully develop more educational resources and orthographies of indigenous languages to meet the demands of multilingual education; 
- Nigerian scholars in the field of language should intensify efforts in the codification of aspects of indigenous languages and produce reading materials;

- The government should do more in the enforcement of the multilingual provisions in all sectors of education;

- A team of experts should be paying constant visits to schools to ensure total adherence to the provisions of multilingual education;

- A credit pass in any of the Nigerian languages should be made a prerequisite to gaining admission into any of the Nigerian Universities;

- Language education programmes should be introduced for schools at basic education level;

- Teachers should be encouraged to jointly help students to develop competence in the use of indigenous languages in a school setting;

- There should be adequate training of teachers;

- The government should make available sufficient funds for implementing educational policies.

\section{CONCLUSION}

It is important to note that there has never been a structured comprehensive language policy in Nigeria. What has been in existence as a language policy that tends to find solution to language concerns in the country is the National Policy on Education drafted in the constitution. It is in connection with this I review this study about language policy and planning on education in Nigeria. The prominence of English and its recognition as language of unity in Nigeria is endangering the Nigerian languages. To preserve the minority languages, the present language policy on education needs to be revised, for example French is no longer relevant in the Nigerian education. On the position of this review with regard to future of English language is that it has been projected as an expansionist language that serves as a threat to the continued development and vitality of other indigenous languages in Nigeria.

\section{REFERENCES}

1. Aghenta, J.A. (1984). Towards a systems approach to the planning of secondary education in

2. Nigeria, in Adesina, Segun and Ogusaju (eds.), Secondary Education in Nigeria, Ile-ife:University of Ife Press.

3. Blench, R. (2002). Research on minority languages in Nigeria. FEL Newsletter 2001 Ognios.

4. Federal Republic of Nigeria (2004). National Policy on Education (Revised). Lagos, Nigeria:Federal Government Press.

5. Gbenedio, B.U. (1990). Problems of implementing the Nigerian National Language Policy. The case of instruction through the mother tongue at the lower primary classes. Ekiadolor Journal of Education. Vol. June p. 47-58.

6. Mohammed, A.M. (2011). TESSA integrated Manual for the re-training of teachers (English Language). Adapted for the FGN/UBE - MDGs 2011. Federal teachers scheme induction/orientation workshop. UBEC. Abuja.

7. Musa, R. J. (2010). The role of mother tongue education in National Development. Social Studies and Integrated National Development in Nigeria, Emman Osakwe (Ed) p. 75 - 82.

8. Musa, R. J. (2012). Language Education in primary Schools in Nigeria: Contemporary issues and New Nigeria. LICE Journal, Vol. 3, Issue 3. 
9. Obanya P. (2004)The Dilemma of Education in Africa. Heinemann Educational Books Nigeria Plc Ibadan.

10. Ogunbiyi O. (2008) The Challenges of Languages Teaching in the 21st Century. Faculty of Education, Lagos State University, Ojo, Nigeria. Medwell Journals Pakistan Journal of Social Sciences 5 (4:) 279 - 299. ISSN: $1683-881$.

11. Okeke, B.S. et. Al. (1985).A handbook on educational administration. Owerri: New African Publishing Co. Ltd.

12. Olagbaju 0.0. (2014).Multilingual Education in Nigeria: Policy, Practice, Challenges and Solutions. Journal of Education and Practice.Vol.5, No.6.

13. Ouadraogo, R.W. (2000). Language planning and language policies in some selected West African Countries. Burkina Faso: IICBA

14. Shaibu, S.D. (2013). Language Policy: Nigeria and the role of English language in the 21st century. European Scientific Journal.Vol. 9, No. 17.

15. Terry, G.R. (1977). Principles of management. Illinions: Richard D. Irwin, Inc.

Citation: Jalaludeen Ibrahim \& Sadiya A. Gwandu Department of European Languages, Federal University Birnin-kebbi, Language Policy on Education in Nigeria: Challenges of Multilingual Education and Future of English Language American ReserachJournal of English and Literature Volume 2, 2016; pp:1-10

Copyright (c) 2016 Jalaludeen Ibrahim \& Sadiya A. Gwandu This is an open access article distributed under the Creative Commons Attribution License, which permits unrestricted use, distribution, and reproduction in any medium, provided the original work is properly cited. 